\title{
KAJIAN KERENTANAN FASILITAS DARAT INA-CBT TERHADAP GUNCANGAN GEMPABUMI
}

\section{VULNERABILITY ASSESSMENT OF INA-CBT ON-SHORE FACILITIES AGAINST EARTHQUAKE SHAKING}

\author{
Mulyo Harris Pradono ${ }^{1}$ \\ ${ }^{1}$ Perekayasa Utama pada Pusat Teknologi Reduksi Risiko Bencana - Badan Pengkajian dan \\ Penerapan Teknologi, JI. M. H. Thamrin No. 8, Jakarta 10340, telepon: (021) 75791378 \\ e-mail: mulyo.harris@bppt.go.id
}

\begin{abstract}
Ina-CBT is an Indonesian Cable-Based Tsunamimeter (or Tsunameter). Ina-CBT is part of the Ina-TEWS (Indonesia Tsunami Early Warning System) which is a tsunami early warning system in Indonesia that aims to provide tsunami early warnings when events occur. This Cable-Based Tsunamimeter consists of an underwater sensor that measures earthquake vibrations and water pressure. Vibration and pressure data are then transmitted through the submarine cable to the mainland. Facilities on land are very important because they send real time data via radio to the monitoring center. Land facilities consist of Beach Manhole, Towers, and Power Houses. All of these facilities must continue to work despite large earthquake shocks which is a sign of tsunami starts. This facility must also be made safe from tsunami attacks. In this paper, the vulnerability of the facility is assessed for earthquake shocks in accordance with applicable standards.
\end{abstract}

Keywords: Ina-CBT, on-shore facilities, triangle tower, monopole tower, earthquake

\begin{abstract}
ABSTRAK
Ina-CBT adalah Indonesia Cable-Based Tsunamimeter (atau Tsunameter). Ina-CBT adalah bagian dari Ina-TEWS (Indonesia Tsunami Early Warning System) yang merupakan sistem peringatan dini tsunami di Indonesia yang bertujuan memberikan peringatan dini tsunami saat kejadian berlangsung. Cable-Based Tsunamimeter ini terdiri dari sensor bawah laut yang mengukur getaran gempa dan tekanan air. Data getaran dan tekanan kemudian diteruskan melalui kabel bawah laut sampai ke daratan. Fasilitas di daratan menjadi sangat penting karena secara real time mengirim data melalui radio ke pusat pemantauan. Fasilitas daratan terdiri dari Beach Manhole (BMH), Menara, dan Rumah Listrik. Semua fasilitas ini harus tetap bekerja walaupun guncangan gempa besar terjadi yang mengawali terjadinya tsunami. Fasilitas ini juga harus dibuat aman terhadap terjangan tsunami. Di dalam makalah ini, kerentanan fasilitas tersebut dikaji terhadap guncangan gempa sesuai dengan standar yang berlaku.
\end{abstract}

Kata kunci: Ina-CBT, fasilitas on-shore, menara segitiga, menara tunggal, gempa

\section{PENDAHULUAN}

\subsection{Latar Belakang}

Pada tahun 2020 ini, pemerintah Indonesia akan membangun fasilitas Ina-CBT di Indonesia. Ina-CBT merupakan singkatan dari Indonesia Cable-Based Tsunamimeter (atau Tsunameter). Ina-CBT merupakan bagian dari Ina-TEWS (Indonesia Tsunami Early Warning System). Ina-TEWS adalah sistem peringatan dini tsunami di Indonesia yang bertujuan memberikan peringatan dini tsunami saat kejadian berlangsung. Selain
Ina-CBT, Ina-TEWS juga menggunakan teknologi Ina-Buoy yang menggunakan pelampung dan sensor bawah laut untuk mendeteksi dini kejadian tsunami. Ina-Buoy tidak dibahas dalam makalah ini.

Ina-CBT mempunyai sensor untuk mengukur perubahan tekanan air bawah laut dan beberapa sensor lainnya. Perubahan tekanan air bawah laut berhubungan dengan kenaikan atau penurunan muka air laut akibat tsunami. Data tekanan ini kemudian dikirimkan ke pusat pemantauan, melalui kabel bawah laut dan melalui fasilitas darat. Fasilitas darat mengirimkan data ke pusat pemantauan 
melalui radio atau melalui satelit. Fasilitas darat terdiri dari Beach Manhole (BMH), menara, dan rumah listrik (power house).

Sesuai dengan rencana kegiatan Ina-CBT di awal tahun 2020, maka penempatan InaCBT akan dilakukan pada 3 lokasi di Indonesia. Ketiga lokasi itu adalah Selat Malaka, Labuan Bajo, dan Rokatenda. Gambar-gambar berikut menunjukkan rencana lokasi Ina-CBT dengan rencana lokasi fasilitas daratnya.

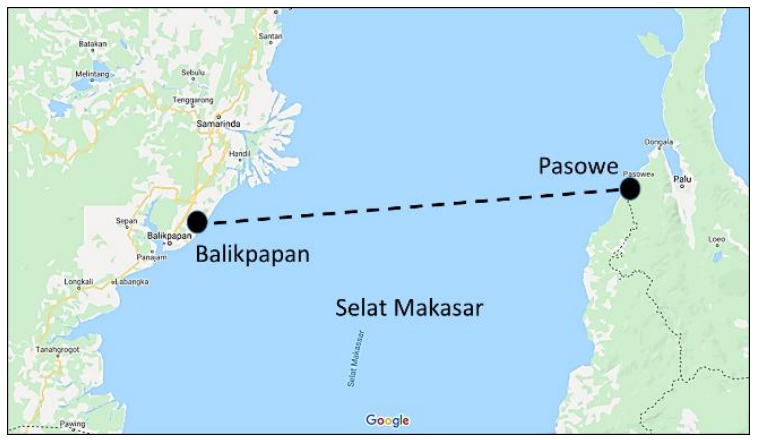

Gambar 1. Lokasi Rencana Jalur Kabel dan Fasilitas Darat di Selat Makassar (Sumber: Peta Google (Google, 2020))

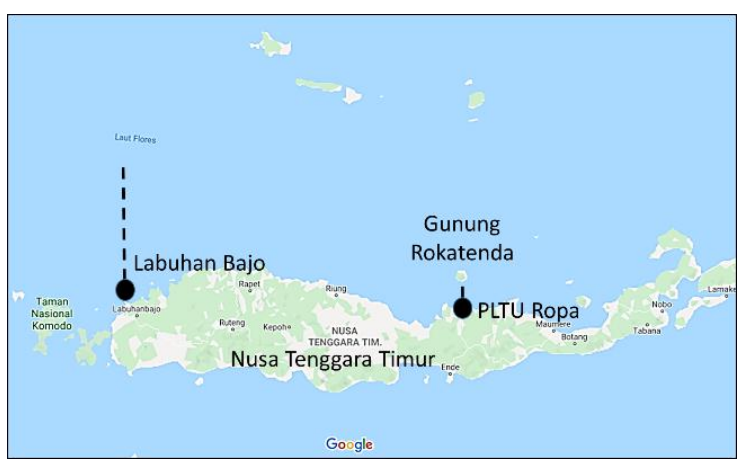

Gambar 2. Lokasi Rencana Jalur Kabel dan Fasilitas Darat di Labuan Bajo dan Rokatenda (Sumber: Peta Google (Google, 2020))

Ina-CBT di Selat Makassar mempunyai dua fasilitas darat, yaitu direncanakan di sekitar Kota Balikpapan dan sekitar Pasowe (Kelurahan Salungkaenu, Kecamatan Banawa Sel., Kabupaten Donggala, Sulawesi Tengah) (Gambar 1). Ina-CBT di Labuan Bajo mempunyai satu fasilitas darat, yaitu di Labuan Bajo (Gambar 2, bagian kiri). Ina-CBT di Rokatenda mempunyai satu fasilitas darat, yaitu di sekitar PLTU Ropa (atau di Kantor Monitoring Gunungapi PVMBG di dekatnya) (Gambar 2, bagian kanan). Ina-CBT Rokatenda dimaksudkan untuk mengantisipasi tsunami akibat longsoran gunungapi Rokatenda di laut yang berada di utara fasilitas PLTU Ropa.

Sebagai fasilitas penyambung informasi dari dasar laut ke darat dan dari darat ke pusat pemantauan, maka fasilitas darat yang terdiri dari Beach Manhole, menara, dan rumah listrik harus kuat dalam menghadapi guncangan gempa besar yang mendahului terjadinya tsunami. Untuk menghadapi gempa besar, kajian mengenai potensi dan lokasi gempa besar sudah dilakukan dan dilaporkan dalam buku Peta Sumber dan Bahaya Gempa Indonesia tahun 2017 (KemenPUPR, 2017). Untuk menghadapi tsunami, fasilitas Beach Manhole akan ditanam di dalam tanah, sedangkan fasilitas rumah listrik dan menara akan dipasang di luar jangkauan tsunami.

Daerah pantai umumnya mempunyai jenis tanah lunak. Sedangkan bangunan menara mempunyai kerentanan yang cukup tinggi pada daerah dengan jenis tanah lunak. Hal ini disebabkan jenis tanah lunak membuat frekuensi dominan getaran gempa menjadi berfrekuensi rendah. Getaran frekuensi rendah ini akan meresonansi menara tinggi yang mempunyai frekuensi alami rendah juga. Bangunan Beach Manhole (BMH) dan rumah listrik mempunyai kerentanan gempabumi yang lebih baik. Hal ini disebabkan $\mathrm{BMH}$ umumnya dibangun di dalam tanah, sedangkan rumah listrik dibangun sebagai bangunan kecil.

\subsection{Tujuan Penelitian}

Tujuan dari penelitian dan kajian ini adalah untuk mengetahui tingkat ancaman gempabumi pada rencana lokasi bangunan darat Ina-CBT dan perilaku bangunan darat Ina-CBT akibat goncangan gempabumi untuk mengetahui tingkat dari kerentanan bangunan tersebut. Tingkat kerentanan terhadap tsunami tidak dibahas, karena menara direncanakan berada di luar jangkauan serangan tsunami. 


\section{BAHAN DAN METODE}

\subsection{Bahan}

Bahan yang digunakan dalam penelitian ini adalah data dimensi dan material menara InaCBT yang akan dibangun menggunakan data menara pada tahun sebelumnya (2019) di lokasi lain. Setiap lokasi mempunyai tingkat ancaman gempa yang berbeda-beda, sehingga hasil kajian pada satu lokasi tidak harus dapat digunakan untuk daerah lain. Bahan lainnya adalah peta ancaman gempa yang didapat dari buku Peta Sumber dan Bahaya Gempa Indonesia tahun 2017 (Kemen PUPR, 2017).

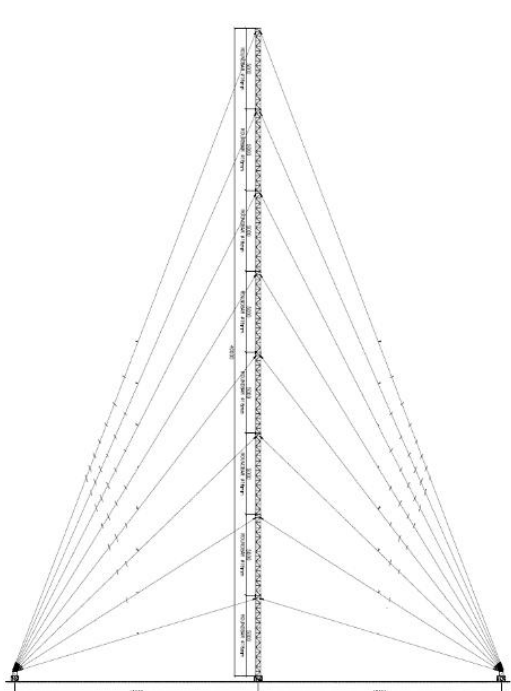

(a)

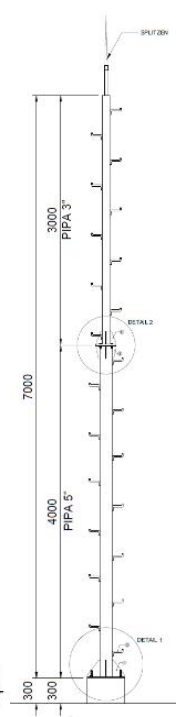

(b)
Gambar 3. Dimensi Menara Fasilitas darat InaCBT (a) Menara Segitiga (Duta Rimba Teknik, 2020a) (b) Menara Tunggal (Duta Rimba Teknik, 2020b)

Peta ancaman gempa di buku Peta Sumber dan Bahaya Gempa Indonesia tahun 2017 (KemenPUPR, 2017) merupakan dasar dalam merancang bangunan aman gempa di Indonesia. Peta ini berisi nilai ancaman gempabumi yang dinyatakan dalam nilai percepatan puncak gempabumi di permukaan tanah (peak ground acceleration). Informasi lainnya adalah berupa probabilitas terjadinya nilai percepatan puncak tersebut. Gambar 4 menunjukkan nilai percepatan gempabumi di batuan dasar di lokasi kajian untuk probabilitas gempa 2500 tahunan. Dengan kata lain, nilai percepatan di sini akan disamai atau dilampaui dengan kemungkinan $2 \%$ dalam 50 tahun.

Selain nilai puncak, dalam membangun struktur aman gempa, diperlukan spektrum respon getaran gempabumi di setiap lokasi tersebut. Untuk ini, Kementerian PUPR telah menyiapkan laman untuk memperoleh spektrum respon getaran gempabumi pada setiap lokasi di Indonesia. Laman tersebut dinamakan Desain Spektra Indonesia (Kemen PUPR, 2011), dan bisa diakses melalui: http://puskim.pu.go.id/Aplikasi/desain_spektra_i ndonesia_2011/

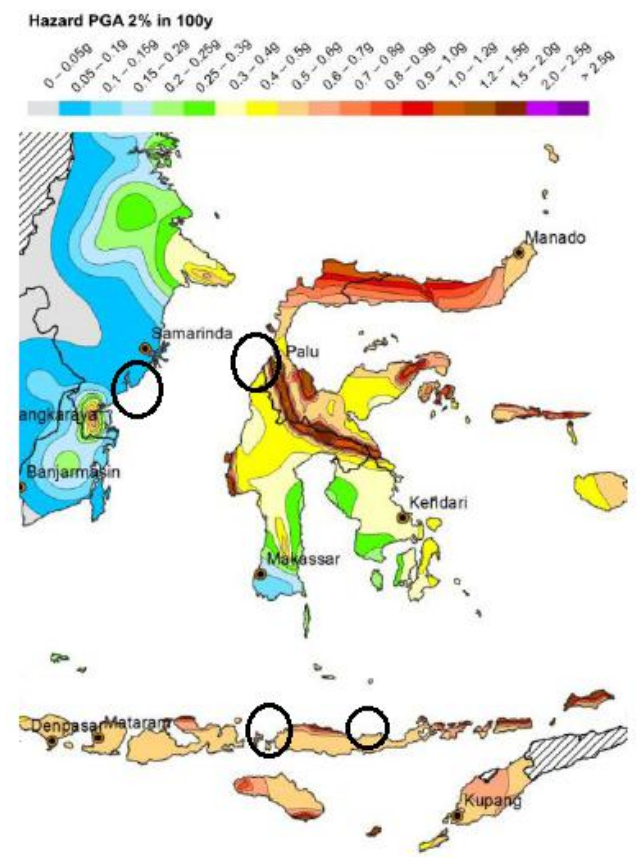

Gambar 4. Nilai Percepatan Gempabumi di Batuan Dasar di Lokasi Kajian (tanda lingkaran) dengan Probabilitas 2\% Dalam 50 Tahun (Gempa 2500 Tahunan) (KemenPUPR, 2017)

\subsection{Metode}

Metode Penelitian yang dilakukan adalah:

a. Mengunjungi laman Desain Spektra Indonesia di atas dan memperoleh desain spektra untuk 4 lokasi fasilitas darat.

b. Melakukan pengumpulan data dimensi menara yang digunakan pada tahun 2019.

c. Melakukan analisis struktur menara segitiga dan menara tunggal pada perangkat lunak pogram analisis struktur, untuk mendapatkan perilaku menara tersebut saat terjadi gempa.

d. Memberikan rekomendasi perancangan menara untuk 4 lokasi fasilitas darat Ina-CBT

Penelitian dilakukan pada bulan Februari Maret 2020, sesuai dengan penjadwalan dari kegiatan Ina-CBT di Pusat Teknologi Reduksi Risiko Bencana.

\section{HASIL DAN PEMBAHASAN}

\subsection{Spektrum Respon Gempa}

\subsubsection{Sekitar Kota Balikpapan}

Wilayah sekitar Kota Balikpapan di Kalimantan akan dipilih sebagai lokasi penempatan fasilitas darat Ina-CBT karena dekat dengan calon Ibu Kota Negara (IKN) dan sudah memiliki fasilitas kelistrikan dan telekomunikasi yang baik. Salah satu tujuan 
dari pemasangan Ina-CBT di Selat Makassar ini adalah untuk memberikan peringatan dini kepada wilayah IKN dan sekitarnya sehingga lebih siaga dalam menghadapi ancaman tsunami di wilayah ini.

Dengan mengunjungi laman yang ditunjukkan pada sub-bab 2.1, maka dengan menentukan lokasi menara, yaitu di sekitar Kota Balikpapan, maka diperoleh Spektrum Respon Gempa pada daerah tersebut yang ditunjukkan pada Gambar 5. Gambar tersebut merupakan nilai spektral percepatan di permukaan dari gempa risk-targeted maximum considered earthquake dengan probabilitas keruntuhan bangunan $1 \%$ dalam 50 tahun.

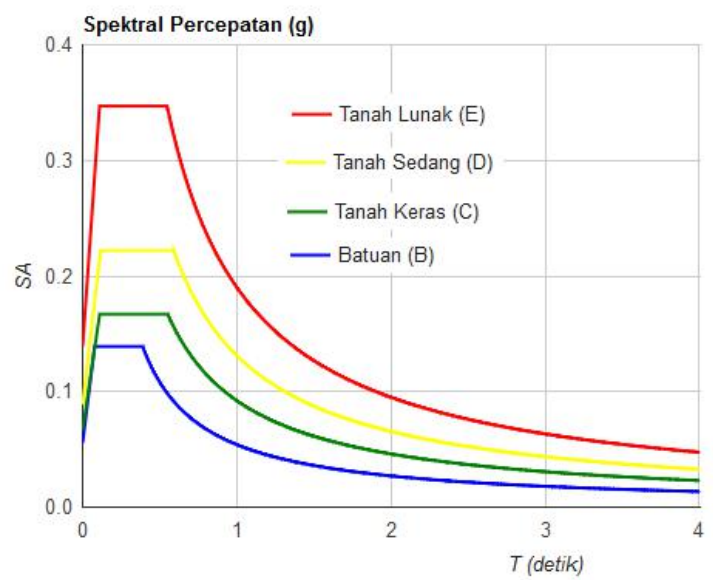

Gambar 5. Spektrum Respon Gempa di Wilayah Sekitar Kota Balikpapan (Kemen PUPR, 2011)

Dengan asumsi bahwa tanah di lokasi pemasangan menara berada sekitar pantai, maka digunakan kurva spektrum pada tanah lunak $(E)$. Dengan kurva ini, jika periode getar alami menara berada pada 0,103 detik - 0,566 detik, maka menara akan menerima percepatan gempa desain sebesar $0,338 \mathrm{~g}$, dengan $g$ adalah percepatan gravitasi $(9,8$ $\mathrm{m} /$ detik $^{2}$ ). Nilai-nilai lain dalam spektrum ini dapat dilihat pada tabel berikut.

Tabel 1. Nilai Variabel Spektrum Respon untuk Jenis Tanah Lunak (E) Lokasi: Kota Balikpapan

\begin{tabular}{c|c}
\multicolumn{2}{c}{ (Kemen PUPR, 2011) } \\
\hline Variabel & Nilai \\
\hline PGA $(\mathrm{g})$ & 0,098 \\
\hline $\mathrm{S}_{\mathrm{S}}(\mathrm{g})$ & 0,203 \\
\hline $\mathrm{S}_{1}(\mathrm{~g})$ & 0,082 \\
\hline $\mathrm{C}_{\mathrm{RS}}$ & 0,930 \\
\hline $\mathrm{C}_{\mathrm{R} 1}$ & 1,190 \\
\hline $\mathrm{F}_{\mathrm{PGA}}$ & 2,500 \\
\hline $\mathrm{F}_{\mathrm{A}}$ & 2,500 \\
\hline $\mathrm{F}_{\mathrm{V}}$ & 3,500 \\
\hline $\mathrm{PSA}_{\mathrm{SA}}(\mathrm{g})$ & 0,246 \\
\hline $\mathrm{S}_{\mathrm{MS}}(\mathrm{g})$ & 0,507 \\
\hline $\mathrm{S}_{\mathrm{M} 1}(\mathrm{~g})$ & 0,287 \\
\hline $\mathrm{S}_{\mathrm{DS}}(\mathrm{g})$ & 0,338
\end{tabular}

\begin{tabular}{c|c}
\hline $\mathrm{S}_{\mathrm{D} 1}(\mathrm{~g})$ & 0,191 \\
\hline $\mathrm{T}_{0}$ (detik) & 0,113 \\
\hline $\mathrm{T}_{\mathrm{S}}$ (detik) & 0,566 \\
\hline
\end{tabular}

Tabel 2. Nilai Spektrum Respon untuk Jenis Tanah Lunak (E) Lokasi: Kota Balikpapan

\begin{tabular}{c|c}
\multicolumn{2}{c}{ (Kemen PUPR, 2011) } \\
\hline $\mathrm{T}_{\text {(detik) }}$ & $\mathrm{SA}(\mathrm{g})$ \\
\hline 0 & 0,135 \\
\hline $\mathrm{T}_{0}$ & 0,338 \\
\hline $\mathrm{T}_{\mathrm{S}}$ & 0,338 \\
\hline $\mathrm{T}_{\mathrm{S}}+0$ & 0,287 \\
\hline $\mathrm{T}_{\mathrm{S}}+0,1$ & 0,250 \\
\hline $\mathrm{T}_{\mathrm{S}}+0,2$ & 0,221 \\
\hline $\mathrm{T}_{\mathrm{S}}+0,3$ & 0,198 \\
\hline $\mathrm{T}_{\mathrm{S}}+0,4$ & 0,179 \\
\hline $\mathrm{T}_{\mathrm{S}}+0,5$ & 0,164 \\
\hline $\mathrm{T}_{\mathrm{S}}+0,6$ & 0,151 \\
\hline $\mathrm{T}_{\mathrm{S}}+0,7$ & 0,140 \\
\hline $\mathrm{T}_{\mathrm{S}}+0,8$ & 0,130 \\
\hline \hline $\mathrm{T}_{\mathrm{S}}+0,9$ & 0,122 \\
\hline $\mathrm{T}_{\mathrm{S}}+1$ & 0,115 \\
\hline $\mathrm{T}_{\mathrm{S}}+1,1$ & 0,108 \\
\hline $\mathrm{T}_{\mathrm{S}}+1,2$ & 0,103 \\
\hline $\mathrm{T}_{\mathrm{S}}+1,3$ & 0,097 \\
\hline $\mathrm{T}_{\mathrm{S}}+1,4$ & 0,093 \\
\hline $\mathrm{T}_{\mathrm{S}}+1,5$ & 0,088 \\
\hline $\mathrm{T}_{\mathrm{S}}+1,6$ & 0,084 \\
\hline $\mathrm{T}_{\mathrm{S}}+1,7$ & 0,081 \\
\hline $\mathrm{T}_{\mathrm{S}}+1,8$ & 0,078 \\
\hline $\mathrm{T}_{\mathrm{S}}+1,9$ & 0,075 \\
\hline $\mathrm{T}_{\mathrm{S}}+2$ & 0,072 \\
\hline 4 & 0,048 \\
\hline
\end{tabular}

\subsubsection{Sekitar Pasowe}

Wilayah pantai sekitar Pasowe (sebelah selatan Donggala) di Pulau Sulawesi akan dipilih sebagai lokasi penempatan fasilitas darat Ina-CBT Selat Makassar untuk sisi Sulawesi karena sudah memiliki fasilitas kelistrikan dan telekomunikasi yang baik.

Sama dengan metode pada sub-bab 3.1.1, maka diperoleh spektrum respon gempa pada pantai sekitar Pasowe yang ditunjukkan pada Gambar 6. Gambar tersebut merupakan nilai spektral percepatan di permukaan dari gempa risk-targeted maximum considered earthquake dengan probabilitas keruntuhan bangunan $1 \%$ dalam 50 tahun. 


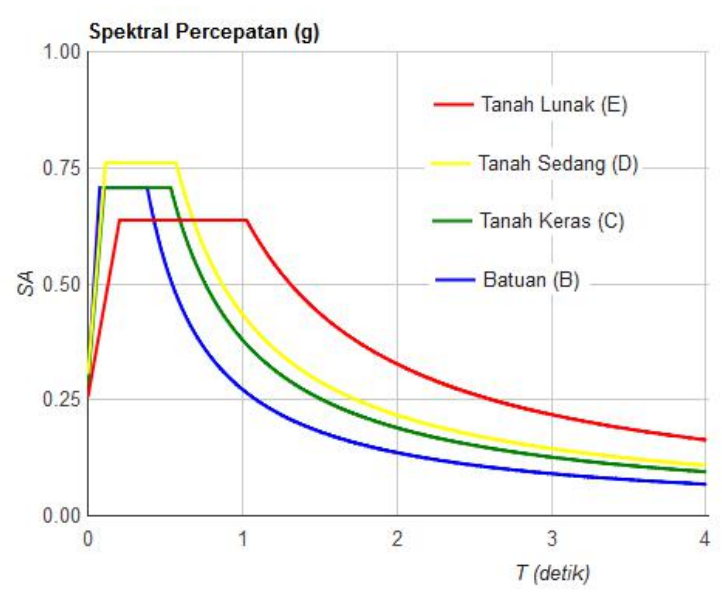

Gambar 6. Spektrum Respon Gempa di Wilayah Sekitar Pasowe di Sulawesi (Kemen PUPR, 2011)

Dengan asumsi bahwa tanah di lokasi pemasangan menara berada sekitar pantai, maka digunakan kurva spektrum pada tanah lunak $(E)$. Dengan kurva ini, jika periode getar alami menara berada pada 0,205 detik - 1,027 detik, maka menara akan menerima percepatan gempa desain sebesar $0,637 \mathrm{~g}$, dengan $g$ adalah percepatan gravitasi $(9,8$ $\mathrm{m} /$ detik $^{2}$ ). Nilai-nilai lain dalam spektrum ini dapat dilihat pada tabel berikut.

Tabel 3. Nilai Variabel Spektrum Respon untukJenis Tanah Lunak (E) Lokasi: Pasowe

\begin{tabular}{c|c}
\multicolumn{2}{c}{ (Kemen PUPR, 2011) } \\
\hline Variabel & Nilai \\
\hline PGA $(g)$ & 0,439 \\
\hline$S_{S}(g)$ & 1,061 \\
\hline$S_{1}(g)$ & 0,409 \\
\hline$C_{R S}$ & 1,099 \\
\hline $\mathrm{C}_{R 1}$ & 1,286 \\
\hline$F_{P G A}$ & 0,900 \\
\hline$F_{A}$ & 0,900 \\
\hline$F_{V}$ & 2,400 \\
\hline$P_{S A}(g)$ & 0,395 \\
\hline$S_{M S}(g)$ & 0,955 \\
\hline$S_{M 1}(g)$ & 0,981 \\
\hline$S_{D S}(g)$ & 0,637 \\
\hline$S_{D 1}(g)$ & 0,654 \\
\hline$T_{0}($ detik) & 0,205 \\
\hline$T_{S}($ detik) & 1,027
\end{tabular}

Tabel 4. Nilai Spektrum Respon untuk Jenis Tanah Lunak (E) Lokasi: Pasowe (Kemen PUPR,

\begin{tabular}{c|c}
\multicolumn{2}{|c}{ 2011) } \\
\hline $\mathrm{T}$ (detik) & $\mathrm{SA}(\mathrm{g})$ \\
\hline 0 & 0,255 \\
\hline $\mathrm{T}_{0}$ & 0,637 \\
\hline $\mathrm{T}_{\mathrm{S}}$ & 0,637 \\
\hline $\mathrm{T}_{\mathrm{S}}+0$ & 0,580 \\
\hline $\mathrm{T}_{\mathrm{S}}+0,1$ & 0,533 \\
\hline $\mathrm{T}_{\mathrm{S}}+0,2$ & 0,493 \\
\hline $\mathrm{T}_{\mathrm{S}}+0,3$ & 0,458 \\
\hline \hline $\mathrm{T}_{\mathrm{S}}+0,4$ & 0,428 \\
\hline $\mathrm{T}_{\mathrm{S}}+0,5$ & 0,402 \\
\hline
\end{tabular}

\begin{tabular}{c|c}
\hline & \\
\hline $\mathrm{T}_{\mathrm{S}}+0,6$ & 0,379 \\
\hline $\mathrm{T}_{\mathrm{S}}+0,7$ & 0,358 \\
\hline $\mathrm{T}_{\mathrm{S}}+0,8$ & 0,339 \\
\hline $\mathrm{T}_{\mathrm{S}}+0,9$ & 0,323 \\
\hline $\mathrm{T}_{\mathrm{S}}+1$ & 0,307 \\
\hline $\mathrm{T}_{\mathrm{S}}+1,1$ & 0,294 \\
\hline $\mathrm{T}_{\mathrm{S}}+1,2$ & 0,281 \\
\hline $\mathrm{T}_{\mathrm{S}}+1,3$ & 0,269 \\
\hline $\mathrm{T}_{\mathrm{S}}+1,4$ & 0,259 \\
\hline $\mathrm{T}_{\mathrm{S}}+1,5$ & 0,249 \\
\hline $\mathrm{T}_{\mathrm{S}}+1,6$ & 0,240 \\
\hline $\mathrm{T}_{\mathrm{S}}+1,7$ & 0,231 \\
\hline $\mathrm{T}_{\mathrm{S}}+1,8$ & 0,223 \\
\hline $\mathrm{T}_{\mathrm{S}}+1,9$ & 0,216 \\
\hline $\mathrm{T}_{\mathrm{S}}+2$ & 0,209 \\
\hline 4 & 0,163 \\
\hline
\end{tabular}

\subsubsection{Sekitar Labuan Bajo}

Wilayah pantai sekitar Labuan Bajo di Pulau Flores akan dipilih sebagai lokasi penempatan fasilitas darat Ina-CBT Labuan Bajo karena sudah memiliki fasilitas kelistrikan dan telekomunikasi yang baik. Sama dengan metode pada sub-bab 3.1.1, maka diperoleh Spektrum Respon Gempa pada pantai Labuan Bajo yang ditunjukkan pada Gambar 7 .

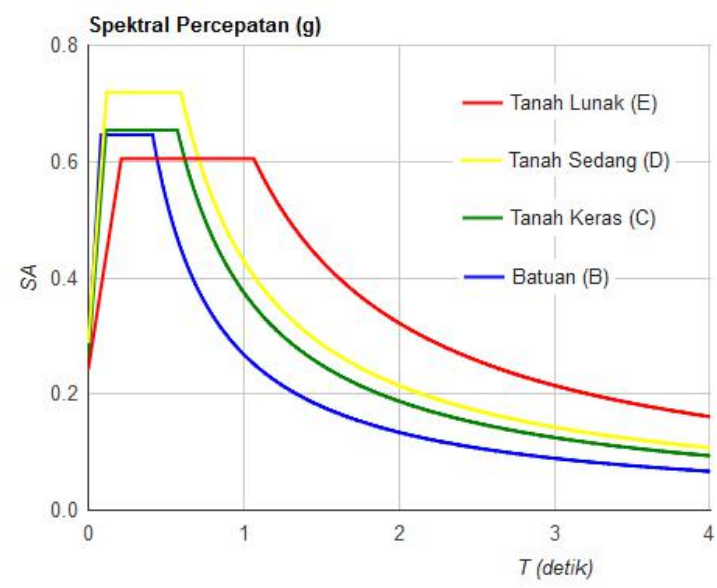

Gambar 7. Spektrum Respon Gempa di Wilayah Pantai Labuan Bajo (Kemen PUPR, 2011)

Dengan asumsi bahwa tanah di lokasi pemasangan menara berada sekitar pantai, maka digunakan kurva spektrum pada tanah lunak $(E)$. Dengan kurva ini, jika periode getar alami menara berada pada 0,213 detik - 1,064 detik, maka menara akan menerima percepatan gempa desain sebesar $0,605 \mathrm{~g}$, dengan $g$ adalah percepatan gravitasi $(9,8$ $\mathrm{m} /$ detik $^{2}$ ). Nilai-nilai lain dalam spektrum ini dapat dilihat pada tabel berikut. 
Tabel 5. Nilai Variabel Spektrum Respon untuk Jenis Tanah Lunak (E) Lokasi: Labuan Bajo

\begin{tabular}{c|c}
\multicolumn{2}{c}{ (Kemen PUPR, 2011) } \\
\hline Variabel & Nilai \\
\hline$P G A(g)$ & 0,447 \\
\hline$S_{S}(g)$ & 0,969 \\
\hline$S_{1}(g)$ & 0,403 \\
\hline $\mathrm{C}_{R S}$ & 1,063 \\
\hline $\mathrm{C}_{\mathrm{R} 1}$ & 0,969 \\
\hline $\mathrm{F}_{\mathrm{PGA}}$ & 0,900 \\
\hline $\mathrm{F}_{\mathrm{A}}$ & 0,937 \\
\hline $\mathrm{F}_{\mathrm{V}}$ & 2,400 \\
\hline $\mathrm{PSA}(\mathrm{g})$ & 0,402 \\
\hline $\mathrm{S}_{\mathrm{MS}}(\mathrm{g})$ & 0,908 \\
\hline $\mathrm{S}_{\mathrm{M} 1}(\mathrm{~g})$ & 0,967 \\
\hline $\mathrm{S}_{\mathrm{DS}}(\mathrm{g})$ & 0,605 \\
\hline $\mathrm{S}_{\mathrm{D} 1}(\mathrm{~g})$ & 0,644 \\
\hline $\mathrm{T}_{0}($ detik) & 0,213 \\
\hline $\mathrm{T}_{\mathrm{S}}($ detik) & 1,064 \\
\hline
\end{tabular}

Tabel 6. Nilai Spektrum Respon untuk Jenis Tanah Lunak (E) Lokasi: Labuan Bajo (Kemen PUPR, 2011)

\begin{tabular}{c|c}
\hline $\mathrm{T}$ (detik) & $\mathrm{SA}(\mathrm{g})$ \\
\hline 0 & 0,242 \\
\hline $\mathrm{T}_{0}$ & 0,605 \\
\hline $\mathrm{T}_{\mathrm{S}}$ & 0,605 \\
\hline $\mathrm{T}_{\mathrm{S}}+0$ & 0,553 \\
\hline $\mathrm{T}_{\mathrm{S}}+0,1$ & 0,510 \\
\hline $\mathrm{T}_{\mathrm{S}}+0,2$ & 0,472 \\
\hline $\mathrm{T}_{\mathrm{S}}+0,3$ & 0,440 \\
\hline $\mathrm{T}_{\mathrm{S}}+0,4$ & 0,412 \\
\hline $\mathrm{T}_{\mathrm{S}}+0,5$ & 0,387 \\
\hline $\mathrm{T}_{\mathrm{S}}+0,6$ & 0,365 \\
\hline $\mathrm{T}_{\mathrm{S}}+0,7$ & 0,346 \\
\hline $\mathrm{T}_{\mathrm{S}}+0,8$ & 0,328 \\
\hline $\mathrm{T}_{\mathrm{S}}+0,9$ & 0,312 \\
\hline $\mathrm{T}_{\mathrm{S}}+1$ & 0,298 \\
\hline $\mathrm{T}_{\mathrm{S}}+1,1$ & 0,285 \\
\hline $\mathrm{T}_{\mathrm{S}}+1,2$ & 0,273 \\
\hline $\mathrm{T}_{\mathrm{S}}+1,3$ & 0,261 \\
\hline $\mathrm{T}_{\mathrm{S}}+1,4$ & 0,251 \\
\hline \hline $\mathrm{T}_{\mathrm{S}}+1,5$ & 0,242 \\
\hline $\mathrm{T}_{\mathrm{S}}+1,6$ & 0,233 \\
\hline $\mathrm{T}_{\mathrm{S}}+1,7$ & 0,225 \\
\hline $\mathrm{T}_{\mathrm{S}}+1,8$ & 0,217 \\
\hline $\mathrm{T}_{\mathrm{S}}+1,9$ & 0,210 \\
\hline $\mathrm{T}_{\mathrm{S}}+2$ & 0,204 \\
\hline 4 & 0,161 \\
\hline
\end{tabular}

\subsubsection{Sekitar PLTU Ropa}

Wilayah pantai sekitar PLTU Ropa di Pulau Flores akan dipilih sebagai lokasi penempatan fasilitas darat Ina-CBT Gunung Rokatenda karena sudah memiliki fasilitas kelistrikan dan telekomunikasi yang baik. Sama dengan metode pada sub-bab 3.1.1, maka diperoleh Spektrum Respon Gempa pada pantai sekitar PLTU Ropa yang ditunjukkan pada Gambar 8.

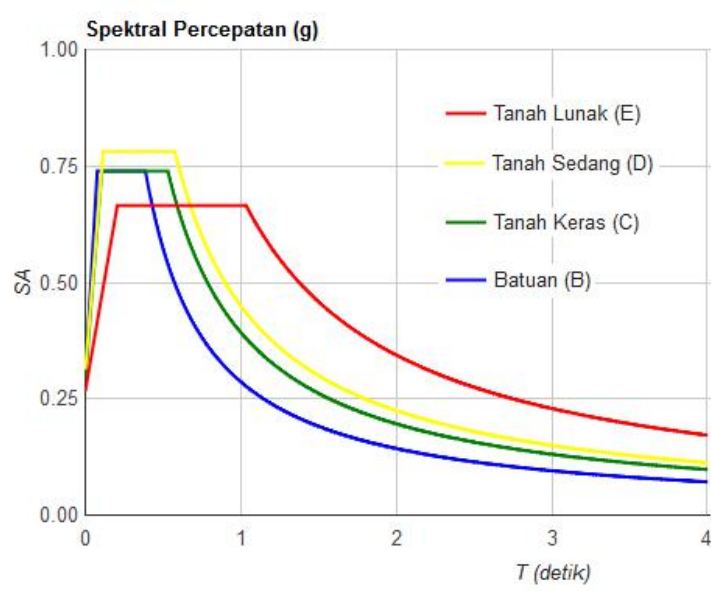

Gambar 8. Spektrum Respon Gempa di Wilayah Pantai PLTU Ropa (Kemen PUPR, 2011)

Dengan asumsi bahwa tanah di lokasi pemasangan menara berada sekitar pantai, maka digunakan kurva spektrum pada tanah lunak (E). Dengan kurva ini, jika periode getar alami menara berada pada 0,206 detik - 1,032 detik, maka menara akan menerima percepatan gempa desain sebesar $0,665 \mathrm{~g}$, dengan $g$ adalah percepatan gravitasi $(9,8$ $\mathrm{m} /$ detik $^{2}$ ). Nilai-nilai lain dalam spektrum ini dapat dilihat pada tabel berikut.

Tabel 7. Nilai Variabel Spektrum Respon untuk Jenis Tanah Lunak (E) Lokasi: Sekitar PLTU

\begin{tabular}{c|c}
\multicolumn{2}{c}{ Ropa (Kemen PUPR, 2011) } \\
\hline Variabel & Nilai \\
\hline PGA $(g)$ & 0,479 \\
\hline$S_{S}(g)$ & 1,109 \\
\hline$S_{1}(g)$ & 0,429 \\
\hline$C_{R S}$ & 1,097 \\
\hline$C_{R 1}$ & 0,992 \\
\hline$F_{P G A}$ & 0,900 \\
\hline$F_{A}$ & 0,900 \\
\hline$F_{V}$ & 2,400 \\
\hline$P_{S A}(g)$ & 0,431 \\
\hline$S_{M S}(g)$ & 0,998 \\
\hline$S_{M 1}(g)$ & 1,030 \\
\hline$S_{D S}(g)$ & 0,665 \\
\hline$S_{D 1}(g)$ & 0,687 \\
\hline$T_{0}($ detik) & 0,206 \\
\hline$T_{S}($ detik) & 1,032
\end{tabular}

Tabel 8. Nilai Spektrum Respon untuk Jenis Tanah Lunak (E) Lokasi: Sekitar PLTU Ropa (Kemen PUPR, 2011)

\begin{tabular}{c|c}
\hline $\mathrm{T}$ (detik) & $\mathrm{SA}(\mathrm{g})$ \\
\hline 0 & 0,266 \\
\hline $\mathrm{T}_{0}$ & 0,665 \\
\hline $\mathrm{T}_{\mathrm{S}}$ & 0,665 \\
\hline $\mathrm{T}_{\mathrm{S}}+0$ & 0,607 \\
\hline $\mathrm{T}_{\mathrm{S}}+0,1$ & 0,557 \\
\hline $\mathrm{T}_{\mathrm{S}}+0,2$ & 0,515 \\
\hline $\mathrm{T}_{\mathrm{S}}+0,3$ & 0,480 \\
\hline
\end{tabular}




\begin{tabular}{c|c}
\hline $\mathrm{T}_{\mathrm{s}}+0,4$ & 0,448 \\
\hline $\mathrm{T}_{\mathrm{s}}+0,5$ & 0,421 \\
\hline $\mathrm{T}_{\mathrm{s}}+0,6$ & 0,396 \\
\hline $\mathrm{T}_{\mathrm{s}}+0,7$ & 0,375 \\
\hline $\mathrm{T}_{\mathrm{S}}+0,8$ & 0,355 \\
\hline $\mathrm{T}_{\mathrm{s}}+0,9$ & 0,338 \\
\hline $\mathrm{T}_{\mathrm{s}}+1$ & 0,322 \\
\hline \hline $\mathrm{T}_{\mathrm{s}}+1,1$ & 0,308 \\
\hline $\mathrm{T}_{\mathrm{S}}+1,2$ & 0,294 \\
\hline $\mathrm{T}_{\mathrm{S}}+1,3$ & 0,282 \\
\hline $\mathrm{T}_{\mathrm{S}}+1,4$ & 0,271 \\
\hline $\mathrm{T}_{\mathrm{s}}+1,5$ & 0,261 \\
\hline $\mathrm{T}_{\mathrm{S}}+1,6$ & 0,251 \\
\hline $\mathrm{T}_{\mathrm{S}}+1,7$ & 0,242 \\
\hline $\mathrm{T}_{\mathrm{S}}+1,8$ & 0,234 \\
\hline $\mathrm{T}_{\mathrm{s}}+1,9$ & 0,226 \\
\hline $\mathrm{T}_{\mathrm{S}}+2$ & 0,219 \\
\hline 4 & 0,172
\end{tabular}

\subsection{Dimensi Menara}

\subsubsection{Menara Segitiga}

Menara segitiga terdiri dari bagian inti yang merupakan rangka segitiga. Bagian inti terdiri dari bar luar dan bar dalam (Duta Rimba Teknik, 2020a). Bar luar dan dalam terbuat dari baja BjTP 24 dengan kuat tarik sebesar $380 \mathrm{MPa}$ dan batas ulur $235 \mathrm{MPa}$ (Badan Standardisasi Nasional, 2002). Gambar bagian inti dari menara segitiga ditunjukkan pada Gambar 9, dengan dimensi:

- Diameter bar luar $16 \mathrm{~mm} \quad\left(A=201 \mathrm{~mm}^{2}\right)$ sehingga $F t=80400 \mathrm{~N}$

- Diameter bar dalam $10 \mathrm{~mm}\left(A=78 \mathrm{~mm}^{2}\right)$ sehingga $F t=31200 \mathrm{~N}$

- Lebar segitiga $300 \mathrm{~mm}$

- Tinggi segmen kecil segitiga $300 \mathrm{~mm}$

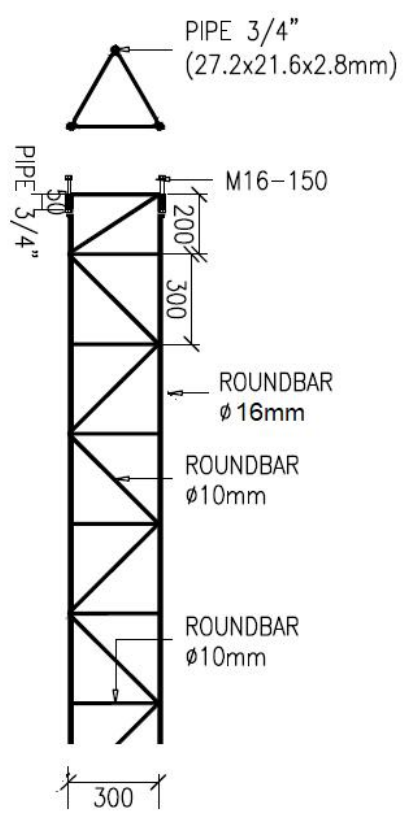

Gambar 9. Bagian Inti dari Menara Segitiga dengan Ketinggian $40 \mathrm{~m}$
Menara segitiga juga terdiri dari bagian penambat berupa beberapa kabel sling yang menambat bagian inti pada 3 sisi. Kabel sling merupakan baja mutu tinggi dengan kuat tarik sebesar $1200 \mathrm{MPa}$. Gambar dari keseluruhan menara segitiga ditunjukkan pada Gambar 10. Dimensi terdiri dari:

- Diameter Sling Penambat $4 \mathrm{~mm}\left(A=12 \mathrm{~mm}^{2}\right)$ sehingga $F t=14400 \mathrm{~N}$

- Jumlah Sling Penambat 8 × 3 sisi

- Jarak Terjauh Sling $15 \mathrm{~m}$

- $\quad$ Sling diikat ke menara setiap $5 \mathrm{~m}$

- Tinggi keseluruhan menara $40 \mathrm{~m}$

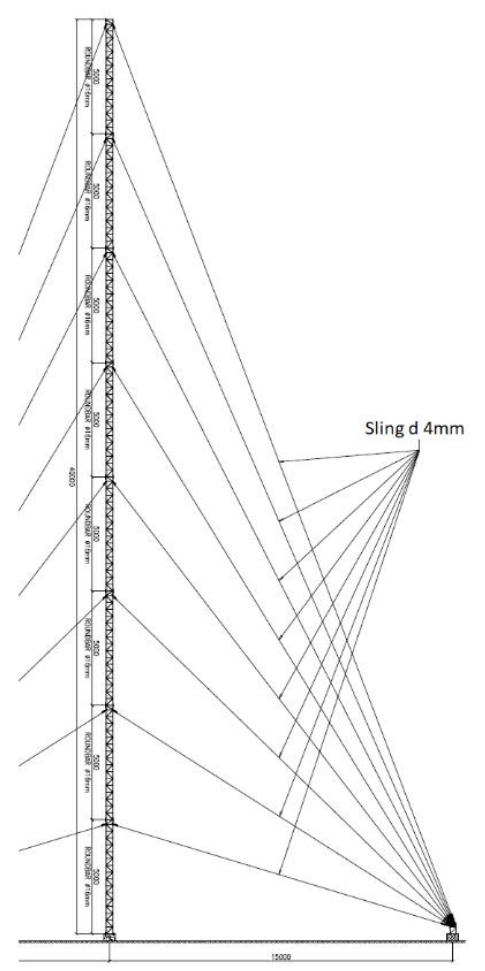

Gambar 10. Gambar Menara Segitiga dengan Ketinggian $40 \mathrm{~m}$

\subsubsection{Menara Tunggal}

Menara tunggal hanya terdiri dari bagian inti yang merupakan tabung silinder (Duta Rimba Teknik, 2020b). Material yang digunakan adalah baja Grade A dengan kuat tarik $310 \mathrm{MPa}$ dan batas ulur $230 \mathrm{MPa}$ (ASTM International, 2015). Gambar dari bagian ini ditunjukkan pada Gambar 11, dengan dimensi:

- Silinder 1 (terbawah): STK 165,2x4,5-2988 $\mathrm{mm}\left(A=2271 \mathrm{~mm}^{2}\right)\left(I=7335677 \mathrm{~mm}^{4}\right)$

- Silinder 2: STK 139,8x4,5-2989 mm $(A=$ $\left.1912 \mathrm{~mm}^{2}\right)\left(I=4379512 \mathrm{~mm}^{4}\right)$

- Silinder 3: STK $114,3 \times 4,5-2990 \mathrm{~mm}(A=$ $\left.1551 \mathrm{~mm}^{2}\right)\left(I=2342006 \mathrm{~mm}^{4}\right)$

- $\quad$ Silinder 4 (teratas): STK 89,1×3,2-2995 mm $\left(A=863 \mathrm{~mm}^{2}\right)\left(I=797208 \mathrm{~mm}^{4}\right)$

Tinggi menara $12 \mathrm{~m}(3 \mathrm{~m} \times 4$ segmen) 


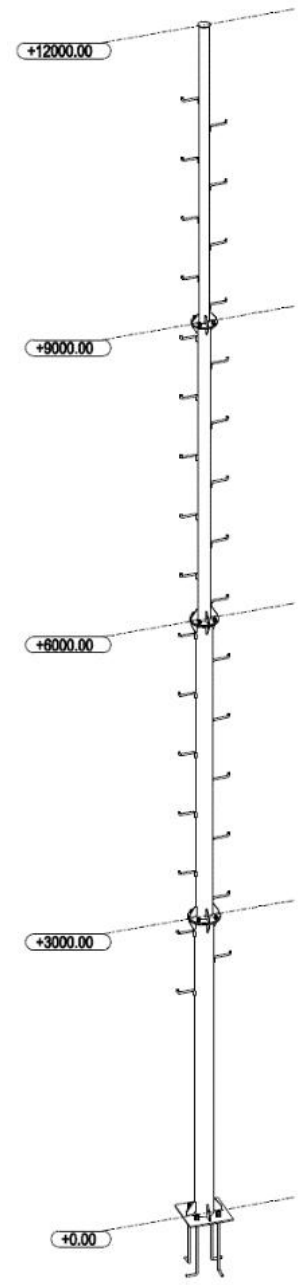

$3 \mathrm{D}$

Gambar 11. Menara Tunggal dengan Ketinggian $12 \mathrm{~m}$

\subsection{Analisis Struktur}

\subsubsection{Menara Segitiga}

Berdasarkan data dimensi dan material pada sub-bab 3.2.1 maka dibuat model struktur menara segitiga pada perangkat lunak Program Analisa Struktur (Computers and Structures, Inc., 2014). Gambar 12 menunjukkan model struktur menara segitiga di atas.

Dari hasil analisis ragam getar, tampak bahwa waktu getar alami struktur masuk kategori frekuensi rendah (antara 0,2 - 1,0 detik). Struktur dengan frekuensi alami rendah, berpotensi teresonansi oleh getaran gempa di daerah berkategori tanah lunak $(E)$, yaitu di lokasi kajian.

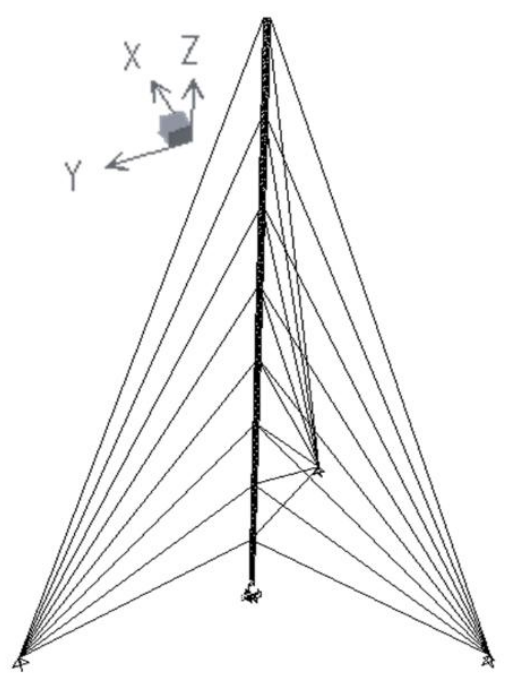

Gambar 12. Model Menara Segitiga dengan Ketinggian $40 \mathrm{~m}$

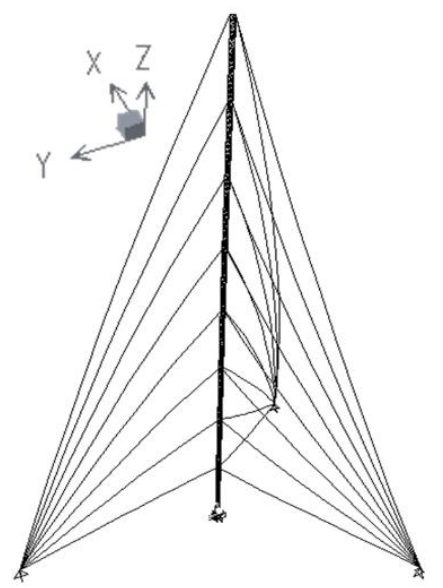

Gambar 13. Ragam Getar ke-1 dengan $T=$ 0,372 detik Model Menara Segitiga

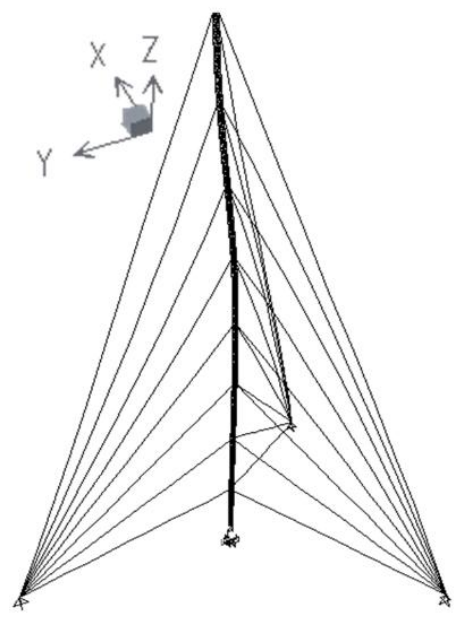

Gambar 14. Ragam Getar ke-3 dengan $T=$ 0,258 detik Model Menara Segitiga 
Analisis struktur selanjutnya adalah melihat pengaruh berat sendiri terhadap gaya yang terjadi pada komponen menara segitiga. Berdasarkan hasil analisis, kabel sling mengalami gaya tekan sebesar 46 Newton, sedangkan komponen batang vertikal di posisi paling bawah mengalami gaya tekan sebesar 1068 Newton.

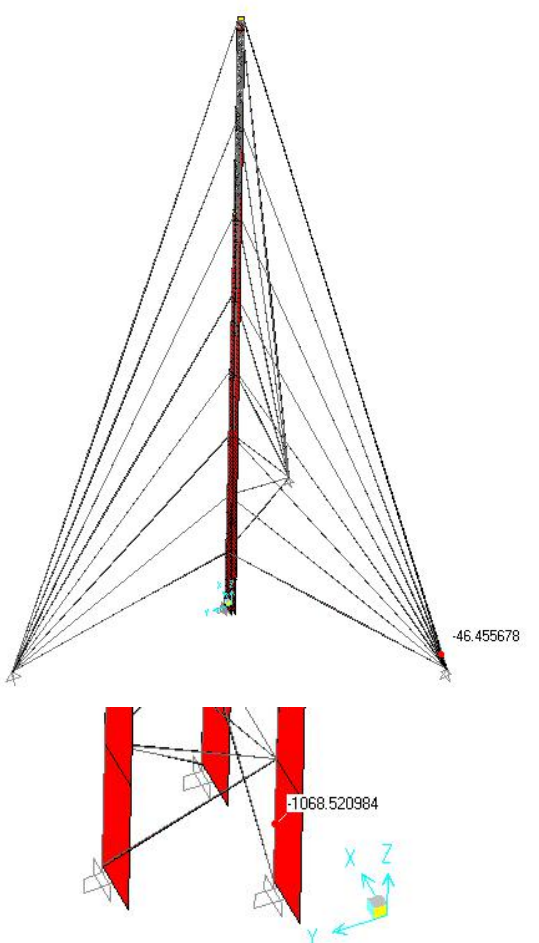

(b)

Gambar 15. Diagram Gaya Aksial pada Komponen Menara Segitiga Akibat Berat Sendiri (a) Sling dan (b) Batang Terbawah

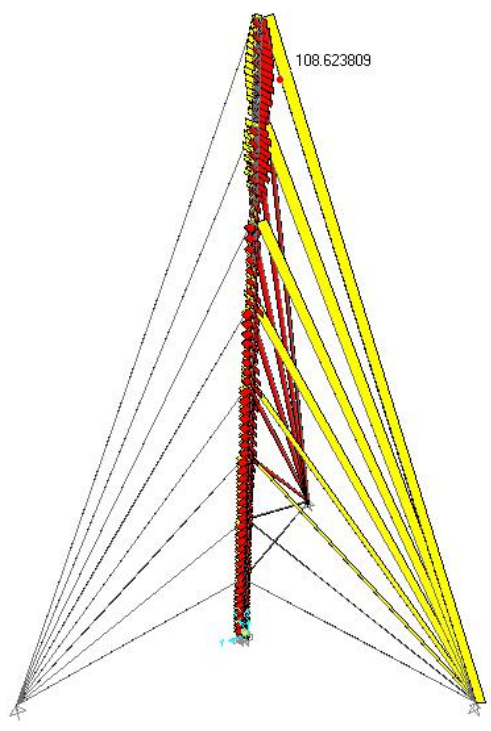

(a)

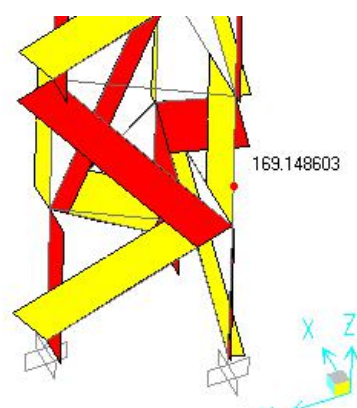

(b)

Gambar 16. Diagram Gaya Aksial pada Komponen Menara Segitiga Akibat Beban Gempa 0,1g arah X (a) Sling dan (b) Batang Terbawah

Analisis struktur dilanjutkan dengan memberikan beban gempa arah $X$ dan $Y$ dengan koefisien gempa sebesar masingmasing $0,1 \mathrm{~g}\left(g=9,81 \mathrm{~m} / \mathrm{detik}^{2}\right)$. Hasil analisis untuk gempa arah $\mathrm{X}$ dapat dilihat pada Gambar 16. Berdasarkan hasil analisis, kabel sling mengalami gaya tarik sebesar 108 Newton, sedangkan komponen batang vertikal di posisi bawah mengalami tarik sebesar 169 Newton dan posisi atas mengalami tekan sebesar 262 Newton.

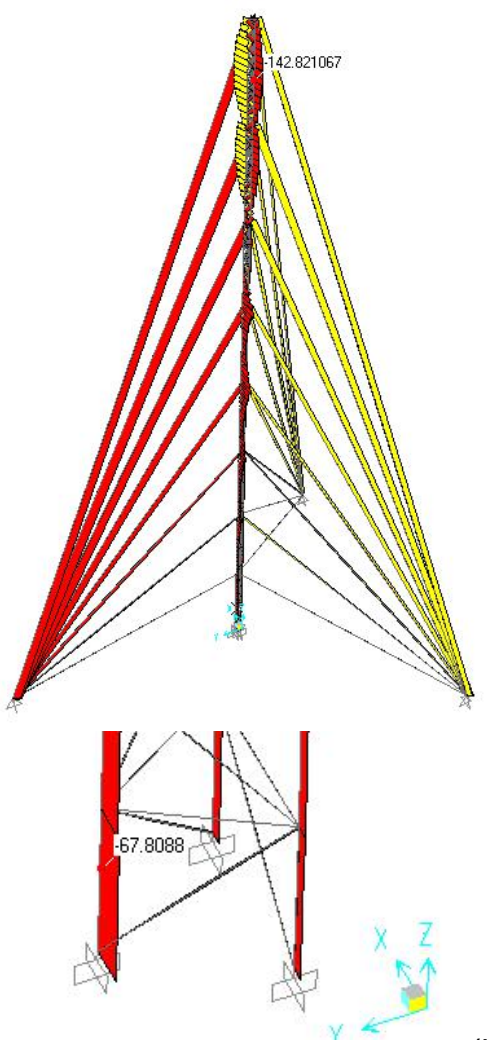

(a)

(b)

Gambar 17. Diagram Gaya Aksial pada Komponen Menara Segitiga Akibat Beban Gempa 0,1g arah Y (a) Sling dan (b) Batang Terbawah 
Hasil analisis untuk gempa arah $\mathrm{Y}$ dapat dilihat pada Gambar 17. Berdasarkan hasil analisis, kabel sling kedua dari atas mengalami gaya tarik sebesar 62 Newton, sedangkan komponen batang vertikal di posisi bawah mengalami tekan sebesar 67 Newton dan posisi atas mengalami tarik sebesar 254 Newton.

Tabel 9. Tegangan pada Struktur akibat Gempa Arah X Sebesar $0,1 \mathrm{~g}$

\begin{tabular}{c|c|c|c|c|c}
\hline $\begin{array}{c}\text { Kom } \\
\text { po- } \\
\text { nen }\end{array}$ & $\begin{array}{c}\text { Gaya } \\
\text { Berat } \\
(\mathrm{N})\end{array}$ & $\begin{array}{c}\text { Tega } \\
-\mathrm{ngan} \\
(\mathrm{N} / \\
\left.\mathrm{mm}^{2}\right)\end{array}$ & $\begin{array}{c}\text { Gaya } \\
\text { Akibat } \\
\text { Gem- } \\
\text { pa (N) }\end{array}$ & $\begin{array}{c}\text { Tega- } \\
\text { ngan } \\
(\mathrm{N} / \\
\left.\mathrm{mm}^{2}\right)\end{array}$ & $\begin{array}{c}\text { Tega- } \\
\text { ngan } \\
\text { Total } \\
(\mathrm{N} / \\
\left.\mathrm{mm}^{2}\right)\end{array}$ \\
\hline B1608 & 1070 & 5,40 & 171 & 0,86 & 7,35 \\
\hline B1605 & 602 & 3,04 & 188 & 0,95 & 4,60 \\
\hline B1602 & 207 & 1,05 & 278 & 1,40 & 2,66 \\
\hline B1008 & 16 & 0,21 & 132 & 1,69 & 1,94 \\
\hline B1005 & 10 & 0,13 & 113 & 1,45 & 1,60 \\
\hline B1002 & 5 & 0,06 & 49 & 0,63 & 0,71 \\
\hline S08 & 6,27 & 0,51 & 18 & 1,45 & 2,06 \\
\hline S06 & 21 & 1,69 & 65 & 5,24 & 7,27 \\
\hline S04 & 34 & 2,74 & 118 & 9,52 & 12,81 \\
\hline S02 & 47 & 3,79 & 108 & 8,71 & 13,26 \\
\hline
\end{tabular}

Tabel 10. Tegangan pada Struktur akibat Gempa Arah Y Sebesar 0,1g

\begin{tabular}{c|c|c|c|c|c}
\hline $\begin{array}{c}\text { Kom } \\
\text { po- } \\
\text { nen }\end{array}$ & $\begin{array}{c}\text { Gaya } \\
\text { Berat } \\
(\mathrm{N})\end{array}$ & $\begin{array}{c}\text { Tega } \\
-\mathrm{ngan} \\
(\mathrm{N} / \\
\left.\mathrm{mm}^{2}\right)\end{array}$ & $\begin{array}{c}\text { Gaya } \\
\text { Akibat } \\
\text { Gem- } \\
\text { pa }(\mathrm{N})\end{array}$ & $\begin{array}{c}\text { Tega- } \\
\text { ngan } \\
(\mathrm{N} / \\
\left.\mathrm{mm}^{2}\right)\end{array}$ & $\begin{array}{c}\text { Tega- } \\
\text { ngan } \\
\text { Total } \\
(\mathrm{N} / \\
\left.\mathrm{mm}^{2}\right)\end{array}$ \\
\hline B1608 & 1070 & 5,40 & 67 & 0,34 & 6,82 \\
\hline B1605 & 602 & 3,04 & 89 & 0,45 & 4,10 \\
\hline B1602 & 207 & 1,05 & 174 & 0,88 & 2,13 \\
\hline B1008 & 16 & 0,21 & 2.3 & 0,03 & 0,28 \\
\hline B1005 & 10 & 0,13 & 6 & 0,08 & 0,23 \\
\hline B1002 & 5 & 0,06 & 12 & 0,15 & 0,23 \\
\hline S08 & 6,27 & 0,51 & 14 & 1,13 & 1,74 \\
\hline S06 & 21 & 1,69 & 26 & 2,10 & 4,13 \\
\hline S04 & 34 & 2,74 & 68 & 5,48 & 8,77 \\
\hline S02 & 47 & 3,79 & 93 & 7,50 & 12,05 \\
\hline
\end{tabular}

Tabel 9 dan 10 menunjukkan besarnya tegangan yang terjadi akibat percepatan gempa respon sebesar 0,1g. Distribusi percepatan gempa pada struktur mengikuti standar SNI 17262012 (Badan Standardisasi Nasional, 2012), dan kombinasi pembebanan mengikuti standar yang sama.

Seperti ditunjukkan pada sub-bab 3.1 (Spektrum Respon Gempa), maka ada empat macam spektrum di keempat lokasi. Dengan waktu getar alami ke-1 menara segitiga adalah $T=0,372$ detik, maka percepatan respon yang akan dialami menara ini ditunjukkan pada Tabel 11. Dari keempat lokasi, maka tiga lokasi (sekitar Pasowe (Sulawesi), Labuan Bajo, dan sekitar PLTU Ropa) mempunyai nilai percepatan respon tinggi, yaitu antara $0,6 \mathrm{~g}$ $0,7 \mathrm{~g}$. Selanjutnya menara segitiga ini dianalisis terhadap gempa dengan percepatan respon sebesar $0,7 \mathrm{~g}$. Hasil ditunjukkan pada tabel 12 dan 13. Berdasarkan standar SNI 17292015 (Badan Standardisasi Nasional, 2015), faktor keamanan untuk tekan dan lentur adalah 1,67. Hasilnya menunjukkan bahwa tegangan yang terjadi pada batang vertikal dan diagonal $(12,53$ MPa dan 12,09 MPa) masih di bawah tegangan ijin dari kuat tarik baja BjTP24 yaitu 235 / 1,67 $=140 \mathrm{MPa}\left(\mathrm{N} / \mathrm{mm}^{2}\right)$.

Sesuai dengan SNI 0076:2008 (Badan Standardisasi Nasional, 2008), maka baja sling mutu $\mathrm{E}$ mempunyai kuat tarik minimum sebesar $1320 \mathrm{MPa}$. Sedangkan tegangan tarik yang terjadi adalah antara 57 - $69 \mathrm{MPa}$, masih di bawah $1320 \mathrm{MPa}$ tersebut.

Tabel 11. Nilai Percepatan Respon Menara Segitiga di Empat Lokasi

\begin{tabular}{c|c|c}
\hline $\begin{array}{c}\text { Waktu } \\
\text { Getar } T \\
\text { (detik) }\end{array}$ & Lokasi & $\begin{array}{c}\text { Percepatan } \\
\text { Spektrum Respon } \\
\text { Tanah Lunak (E) } \\
\text { (g) }\end{array}$ \\
\hline 0,372 & $\begin{array}{c}\text { Sekitar } \\
\text { Balikpapan }\end{array}$ & 0,338 \\
\hline 0,372 & Sekitar Pasowe & 0,637 \\
\hline 0,372 & Labuan Bajo & 0,605 \\
\hline 0,372 & $\begin{array}{c}\text { Sekitar PLTU } \\
\text { Ropa }\end{array}$ & 0,665 \\
\hline
\end{tabular}

Tabel 12. Tegangan pada Struktur akibat Gempa Arah X Sebesar 0,7g

\begin{tabular}{c|c|c|c|c|c}
\hline $\begin{array}{c}\text { Komp } \\
\text { o-nen }\end{array}$ & $\begin{array}{c}\text { Gaya } \\
\text { Berat } \\
(\mathrm{N})\end{array}$ & $\begin{array}{c}\text { Tega- } \\
\text { ngan } \\
(\mathrm{N} / \\
\left.\mathrm{mm}^{2}\right)\end{array}$ & $\begin{array}{c}\text { Gaya } \\
\text { Akibat } \\
\text { Gem- } \\
\mathrm{pa}(\mathrm{N})\end{array}$ & $\begin{array}{c}\text { Tega- } \\
\text { ngan } \\
(\mathrm{N} / \\
\left.\mathrm{mm}^{2}\right)\end{array}$ & $\begin{array}{c}\text { Tega- } \\
\text { ngan } \\
\text { Total } \\
(\mathrm{N} / \\
\left.\mathrm{mm}^{2}\right)\end{array}$ \\
\hline B1608 & 1070 & 5,40 & 1197 & 6,05 & 12,53 \\
\hline B1605 & 602 & 3,04 & 1316 & 6,65 & 10,29 \\
\hline B1602 & 207 & 1,05 & 1946 & 9,83 & 11,08 \\
\hline B1008 & 16 & 0,21 & 924 & 11,85 & 12,09 \\
\hline B1005 & 10 & 0,13 & 791 & 10,14 & 10,29 \\
\hline B1002 & 5 & 0,06 & 343 & 4,40 & 4.47 \\
\hline S08 & 6,27 & 0,51 & 126 & 10,16 & 10,77 \\
\hline S06 & 21 & 1,69 & 455 & 36,69 & 38,73 \\
\hline S04 & 34 & 2,74 & 826 & 66,61 & 69,90 \\
\hline S02 & 47 & 3,79 & 756 & 60,97 & 65,52 \\
\hline
\end{tabular}


Tabel 13. Tegangan pada Struktur akibat Gempa Arah Y Sebesar $0,7 \mathrm{~g}$

\begin{tabular}{c|c|c|c|c|c}
\hline $\begin{array}{c}\text { Kom } \\
\text { po- } \\
\text { nen }\end{array}$ & $\begin{array}{c}\text { Gaya } \\
\text { Berat } \\
(\mathrm{N})\end{array}$ & $\begin{array}{c}\text { Tega } \\
-\mathrm{ngan} \\
(\mathrm{N} / \\
\left.\mathrm{mm}^{2}\right)\end{array}$ & $\begin{array}{c}\text { Gaya } \\
\text { Akibat } \\
\text { Gem- } \\
\text { pa (N) }\end{array}$ & $\begin{array}{c}\text { Tega- } \\
\text { ngan } \\
(\mathrm{N} / \\
\left.\mathrm{mm}^{2}\right)\end{array}$ & $\begin{array}{c}\text { Tega- } \\
\text { ngan } \\
\text { Total } \\
(\mathrm{N} / \\
\left.\mathrm{mm}^{2}\right)\end{array}$ \\
\hline B1608 & 1070 & 5,40 & 469 & 2,37 & 8,85 \\
\hline B1605 & 602 & 3,04 & 623 & 3,15 & 6,79 \\
\hline B1602 & 207 & 1,05 & 1218 & 6,15 & 7,41 \\
\hline B1008 & 16 & 0,21 & 16,1 & 0,21 & 0,45 \\
\hline B1005 & 10 & 0,13 & 42 & 0,54 & 0,69 \\
\hline B1002 & 5 & 0,06 & 84 & 1,08 & 1,15 \\
\hline S08 & 6,27 & 0,51 & 98 & 7,90 & 8,51 \\
\hline S06 & 21 & 1,69 & 182 & 14,68 & 16,71 \\
\hline S04 & 34 & 2,74 & 476 & 38,39 & 41,68 \\
\hline S02 & 47 & 3,79 & 651 & 52,50 & 57,05 \\
\hline
\end{tabular}

Rekomendasi yang dapat disampaikan sehubungan dengan hasil di atas adalah:

- Menara tunggal dengan ketinggian 42 meter dengan dimensi seperti di atas dapat dipasang di keempat lokasi.

- Untuk menara tunggal dengan dimensi lain, misalnya harus lebih tinggi, atau berada di lokasi lain, maka perlu analisis lebih lanjut.

- Kuat pondasi harus disesuaikan dengan hasil di atas. Pondasi harus mampu menahan gaya berat sebesar 1761 kN (176 ton) dan harus mampu menahan momen sebesar 9478 kN.mm (9,478 kN.m). Jika tidak, maka kerusakan bisa terjadi pada pondasinya.

- Material menara yang digunakan harus mampu menahan serangan fisik dan kimiawi lingkungan sekitarnya untuk selama masa layan Ina-CBT ini.

\subsubsection{Menara Tunggal}

Berdasarkan data dimensi dan material pada sub-bab 3.2.2 maka dibuat model struktur menara tunggal pada perangkat lunak Program Analisa Struktur (Computers and Structures, Inc., 2014). Gambar 18 menunjukkan model struktur menara tunggal tersebut.

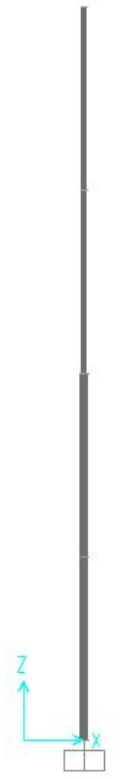

(a)

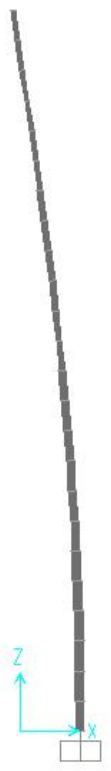

(b)

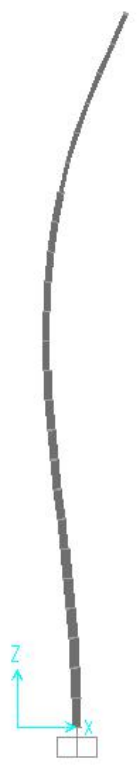

(c)

Gambar 18. (a) Model Menara Tunggal dengan Ketinggian 12 m (b) Ragam Getar ke-1 dengan $T=0,845$ dan (c) Ragam Getar ke-3 dan $T=$ 0,206 detik (Hasil Analisis dalam Perangkat Lunak)

Dari hasil analisis ragam getar di atas, tampak bahwa waktu getar alami struktur masuk kategori frekuensi rendah (antara 0,2 1,0 detik). Struktur dengan frekuensi alami rendah, berpotensi teresonansi oleh getaran gempa di daerah berkategori tanah lunak $(E)$, yaitu di lokasi kajian.

Analisis struktur selanjutnya adalah melihat pengaruh berat sendiri terhadap gaya yang terjadi pada komponen menara segitiga. Diagram gaya aksial akibat berat sendiri ditunjukkan pada Gambar 19(a). Berdasarkan hasil analisis, komponen batang pipa di posisi paling bawah mengalami gaya tekan sebesar 1761 Newton. Analisis struktur dilanjutkan dengan memberikan beban gempa arah $X$ saja (karena simetris dengan arah $\mathrm{Y}$ ) dengan koefisien gempa sebesar $0,1 g \quad(g=9,81$ $\mathrm{m} /$ detik $^{2}$ ). Hasil analisis untuk gempa arah $X$ dapat dilihat pada Gambar 19(b). Berdasarkan hasil analisis, komponen batang pipa di posisi paling bawah mengalami momen sebesar 1354824 Newton.mm (1,354 kN.m). 


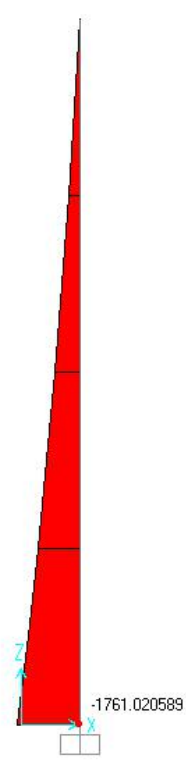

(a)

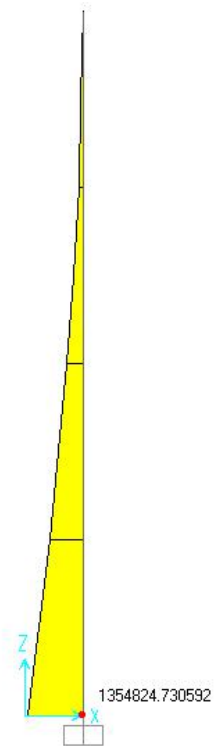

(b)

Gambar 19. (a) Diagram Gaya Aksial Akibat Berat Sendiri dan (b) Diagram Momen Akibat Gempa arah X pada Batang Menara Tunggal

Tabel 14. Tegangan pada Struktur akibat

Gempa Arah X Sebesar 0,1g (Hasil Analisis dalam Perangkat Lunak)

\begin{tabular}{c|c|c|c|c|c}
\hline Pipa & $\begin{array}{c}\text { Gaya } \\
\text { Berat } \\
(\mathrm{N})\end{array}$ & $\begin{array}{c}\text { Tega- } \\
\text { ngan } \\
(\mathrm{N} / \\
\left.\mathrm{mm}^{2}\right)\end{array}$ & $\begin{array}{c}\text { Momen } \\
\text { Gempa } \\
(\mathrm{kN} . \\
\mathrm{mm})\end{array}$ & $\begin{array}{c}\text { Tega- } \\
\text { ngan } \\
(\mathrm{N} / \\
\left.\mathrm{mm}^{2}\right)\end{array}$ & $\begin{array}{c}\text { Tegan } \\
- \text { gan } \\
\text { Total } \\
(\mathrm{N} / \\
\left.\mathrm{mm}^{2}\right)\end{array}$ \\
\hline 1 & 1761 & 0,78 & 1354 & 15,25 & 16,18 \\
\hline 2 & 1183 & 0,62 & 826 & 13,18 & 13,93 \\
\hline 3 & 698 & 0,45 & 389 & 9,49 & 10,03 \\
\hline 4 & 303 & 0,35 & 104 & 5,81 & 6,23 \\
\hline
\end{tabular}

Tabel 14 menunjukkan besarnya tegangan yang terjadi akibat percepatan gempa respon sebesar 0,1g. Distribusi percepatan gempa pada struktur mengikuti standar SNI 17262012 (Badan Standardisasi Nasional, 2012), dan kombinasi pembebanan mengikuti standar yang sama.

Seperti ditunjukkan pada sub-bab 3.1 (Spektrum Respon Gempa), maka ada empat macam spektrum di keempat lokasi. Dengan waktu getar alami ke-1 menara tunggal adalah $T=0,845$ detik, maka percepatan respon yang akan dialami menara ini ditunjukkan pada Tabel 15. Dari keempat lokasi, maka tiga lokasi mempunyai nilai percepatan respon tinggi, yaitu antara $0,6 g-0,7 g$. Selanjutnya menara tunggal ini dianalisis terhadap gempa dengan percepatan respon sebesar 0,7g. Hasil ditunjukkan pada Tabel 16. Berdasarkan standar SNI 17292015 (Badan Standardisasi Nasional, 2015), faktor keamanan untuk tekan dan lentur adalah 1,67. Hasilnya menunjukkan bahwa tegangan yang terjadi pada pipa/tabung menara $(107,65 \mathrm{MPa})$ masih di bawah tegangan izin dari kuat tarik baja BjTP24 yaitu $235 / 1,67=140 \mathrm{MPa}\left(\mathrm{N} / \mathrm{mm}^{2}\right)$.

Tabel 15. Nilai Percepatan Respon Menara Tunggal di Empat Lokasi

\begin{tabular}{c|c|c}
\hline $\begin{array}{c}\text { Waktu } \\
\text { (detar } T\end{array}$ & Lokasi & $\begin{array}{c}\text { Percepatan } \\
\text { Spektrum Respon } \\
\text { Tanah Lunak (E) } \\
(\mathrm{g})\end{array}$ \\
\hline 0,845 & $\begin{array}{c}\text { Sekitar } \\
\text { Balikpapan }\end{array}$ & 0,338 \\
\hline 0,845 & Sekitar Pasowe & 0,637 \\
\hline 0,845 & Labuan Bajo & 0,605 \\
\hline 0,845 & $\begin{array}{c}\text { Sekitar PLTU } \\
\text { Ropa }\end{array}$ & 0,665 \\
\hline
\end{tabular}

Tabel 16. Tegangan pada Komponen Struktur akibat Gempa Arah X Sebesar 0,7g

\begin{tabular}{|c|c|c|c|c|c|}
\hline Pipa & $\begin{array}{c}\text { Gaya } \\
\text { Berat } \\
(\mathrm{N})\end{array}$ & $\begin{array}{c}\text { Tega- } \\
\text { ngan } \\
(\mathrm{N} / \\
\left.\mathrm{mm}^{2}\right)\end{array}$ & $\begin{array}{c}\text { Momen } \\
\text { Gempa } \\
(\mathrm{kN} . \\
\mathrm{mm})\end{array}$ & $\begin{array}{l}\text { Tega- } \\
\text { ngan } \\
(\mathrm{N} / \\
\left.\mathrm{mm}^{2}\right)\end{array}$ & $\begin{array}{c}\text { Tegan } \\
\text {-gan } \\
\text { Total } \\
(\mathrm{N} / \\
\left.\mathrm{mm}^{2}\right) \\
\end{array}$ \\
\hline 1 & 1761 & 0,78 & 9478 & 106,72 & 107,65 \\
\hline 2 & 1183 & 0,62 & 5782 & 92,28 & 93,03 \\
\hline 3 & 698 & 0,45 & 2723 & 66,45 & 66,99 \\
\hline 4 & 303 & 0,35 & 728 & 40,68 & 41,10 \\
\hline
\end{tabular}

Rekomendasi yang dapat disampaikan sehubungan dengan hasil di atas adalah:

- Menara tunggal dengan ketinggian 12 meter dengan dimensi seperti di atas dapat dipasang di keempat lokasi.

- Untuk menara tunggal dengan dimensi lain, misalnya harus lebih tinggi, atau berada di lokasi lain, maka perlu analisis lebih lanjut.

- Kuat pondasi harus disesuaikan dengan hasil di atas. Pondasi harus mampu menahan gaya berat sebesar 1761 kN (176 ton) dan harus mampu menahan momen sebesar 9478 kN.mm $(9,478$ kN.m). Jika tidak, maka kerusakan bisa terjadi pada pondasinya.

- Material menara yang digunakan harus mampu menahan serangan fisik dan kimiawi lingkungan sekitarnya untuk selama masa layan Ina-CBT ini. 


\section{KESIMPULAN}

Kesimpulan dari hasil kajian:

- Kajian kerentanan gempabumi telah dilakukan terhadap fasilitas darat Ina-CBT berupa menara segitiga dan menara tunggal pada empat calon lokasi: sekitar Kota Balikpapan, sekitar Pasowe (Sulawesi), Labuan Bajo, dan sekitar PLTU Ropa.

- Keempat calon lokasi mempunyai tingkat ancaman gempa sedang (sekitar Kota Balikpapan) sampai dengan tinggi (sekitar Pasowe (Sulawesi), Labuan Bajo, dan sekitar PLTU Ropa). Tingkat sedang ditunjukkan dengan percepatan response sebesar $0,338 \mathrm{~g}$ dan tingkat tinggi ditunjukkan dengan $0,665 \mathrm{~g}$.

- Hasil kajian terhadap menara segitiga dan menara tunggal menunjukkan bahwa menara-menara tersebut mampu menahan percepatan respon gempa sampai dengan $0,7 g$.

Rekomendasi dari hasil kajian:

- Kuat pondasi harus disesuaikan dengan hasil di atas. Pondasi harus mampu menahan gaya aksial dan momen (untuk menara tunggal). Jika kekuatan pondasi tidak terpenuhi, maka kegagalan akan terjadi pada pondasi.

- Material menara yang digunakan harus mampu menahan serangan fisik dan kimiawi lingkungan sekitarnya selama masa layan Ina-CBT ini.

- Menara-menara dengan dimensi selain di atas dan ditempatkan di lokasi lain, maka harus dianalisis lagi lebih lanjut.

\section{PERSANTUNAN}

Kegiatan ini didanai dari DIPA PTRRB 2020 yaitu Inovasi Sistem dan Teknologi Indonesia Tsunami Early Warning System (InaTEWS). Kegiatan kajian kerentanan fasilitas Ina-CBT di darat merupakan bagian dari Desk Top Study yang dilakukan di awal kegiatan. Ucapan terima kasih disampaikan kepada rekan-rekan di PTRRB dan B2TKS yang membantu dalam perolehan data sekunder menara dan fasilitas lainnya.

\section{DAFTAR PUSTAKA}

ASTM International. 2015. A500/A500M - 13 Standard Specification for Cold-Formed Welded and Seamless Carbon Steel
Structural Tubing in Rounds and Shapes. $6 \mathrm{p}$.

Badan Standardisasi Nasional. 2002. SNI 072052-2002 Baja Tulangan Beton. 15p.

Badan Standardisasi Nasional. 2008. SNI 0076:2008 Tali Kawat Baja, 24p.

Badan Standardisasi Nasional. 2012. SNI 1726:2012 Tatacara Perencanaan Ketahanan Gempa untuk Struktur Bangunan Gedung dan Non Gedung. 196p.

Badan Standardisasi Nasional. 2015. SNI 1155:2011 Kawat Baja Tanpa Lapisan untuk Konstruksi Beton Pratekan, 10p.

Badan Standardisasi Nasional. 2015. SNI 1729:2015 Spesifikasi untuk Bangunan Gedung Baja Struktural. 290p.

Computers and Structures, Inc. 2014. SAP2000 Linear and Nonlinear Static and Dynamic Analysis and Design of Three-Dimensional Structures, Advanced 14.0.0.

Duta Rimba Teknik. 2020a. Drawing Guyed 40 Meter [terhubung berkala] http://www.cvdutarimba.com/search/label/G UYED\%2040\%20M?m=0 [16 Maret 2020] 